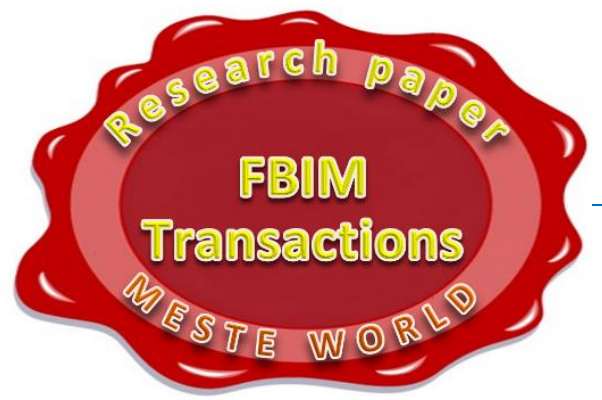

\title{
STAVOVI MLADIH PREMA ELEKTRONSKOM GLASANJU
}

\section{ATTITUDES OF YOUNG PEOPLE TOWARDS ELECTRONIC VOTING}

\section{Dragoljub Pilipović}

Fakultet za informacione tehnologije, Slobomir P Univerzitet, Bijeljina, BiH

\section{Željko Gavrić}

Fakultet organizacionih nauka, Univerzitet u Beogradu, Beograd, Srbija

OMESTE

JEL Category: C12, 033, P48

\begin{abstract}
Apstrakt
Svaka državna struktura se može posmatrati kao servis građana pa tako i elektronska vlada. U radu je zato analiziran jedan takav servis - servis elektronskog glasanja. Elektronsko glasanje (skraćeno eglasanje) predstavlja jedno od formi udaljenog glasanja koje se prvenstveno koristi na održanim političkim izborima. E-glasanje se ogleda u upotrebi bar jednog elektronskog uređaja u svrhu funkcionisanja servisa. Svaki sistem za e-glasanje ima svoje zahteve, karakteristike i osobine, ali je isto tako važno percepcija njegovih korisnika - glasača. U ovom radu se ispituje dejstvo socio-demografskih faktora (poput pola, starosti, fakulteta i polja kome pripada fakultet) na spremnost mladih za korišćenje e-glasanja na izborima. Dosadašnja sociološka istraživanja su pokazala da su mladi ljudi među vodećim slojevima društva po pitanju njihove spremnosti da iskoriste prednosti koje pružaju nove IKT, gde spada $i$ servis elektronskog glasanja. $U$ tom smislu nastojaće se da na primeru mladih, studenata na svim fakultetima i odeljenjima jednog univerziteta, utvrdimo kakvi su stavovi mladih prema e-glasanju i da li postoji pravilnost odnosno povezanost između nekih socio-demografskih faktora i stava prema eglasanju.
\end{abstract}

KIjučne reči: IKT, e-demokratija, e-glasanje, studenti, anketa, SPSS.

\section{Abstract \\ Adresa autora zaduženog za korespodenciju Dragoljub Pilipović \\ 靠"dragoljub.pilipovic@gmail.com}

Every state structure can be seen as a service to citizens, including e-government. That is why one such service will be described - the electronic voting service. Electronic voting (abbreviated e-voting) is one of the forms of remote voting that is primarily used in political elections. E-voting is reflected in the use of at least one electronic device for the service. Each e-voting system has its requirements, characteristics, and features, but the perception of its users - voters is also important. This paper examines the effect of socio-demographic factors (such as gender, age, faculty, and field to which the faculty belongs) on the readiness 
of young people to use e-voting in elections. Sociological research to date has shown that young people are among the leading strata of society in terms of their willingness to take advantage of the new ICTs, including e-voting. In that sense, we will try to determine the attitudes of young people towards e-voting on the example of young people, students at all faculties and departments of one university, and whether is there a regularity or connection between some socio-demographic factors and attitudes towards evoting.

Keywords: ICT, e-democracy, e-voting, students, survey, SPSS.

\section{UVOD}

Elektronska demokratija (skraćeno edemokratija) je jedna faza istorijskog razvoja demokratije u društvima. Ostali izrazi koji se koriste paralelno su teledemokratija, digitalna demokratija, kiber demokratija, virtuelna demokratija, Internet demokratija i ponekad elektronska republika. Ipak u ovom radu glavni pojam je više tehnološko-inženjerske provenijencije $\mathrm{i}$ to je e-glasanje. Sam naziv elektronskog glasanja ukazuje na upotrebu određenih elektronskih uređaja i obradu podataka tokom procesa glasanja.

Opšti razvoj na polju teme e-glasanja i njegova značajnost i uticaj na mrežu naučnih radnika analizirani su u (Krimmer, R., Volkamer, M., \& Dueñas-Cid, D, 2019).

Najčešći istraživački radovi opisuju šemu eglasanja (e-voting scheme), što tradicionalno uključuje: a) mix mreže, b) oglasne table, c) "slepe" potpise, d) homomorfne enkripcije, e) vizuelnu kriptografiju, itd. Kratak pregled šema prikazan je u (Mursi, M. F., Assassa, G. M., Abdelhafez, A., \& Samra, K. M. A., 2013).

Ostali radovi, takođe brojni, bave se posebnim karakteristikama vezanim za elektronsko glasanje. $U$ tom kontekstu, jedna od najrelevantnijih karakteristika je upotrebljivost (engl. usability) opisana, na primer, u (Kulyk O., Volkamer M., 2018) i (Wang, K. H., Mondal, S. K., Chan, K., Xie, X., 2017). Druga relevantna karakteristika proverljivost (engl. verifiability), analizirana je u (Kusters, R., Truderung, T., Vogt, A., 2012) i (Cortier, V., Galindo, D., Küsters, R., Mueller, J., Truderung, T., 2016).

Uspeh blockchain tehnologija, svima poznata kriptovaluta, Bitcoin prebacio je ovu tehnologiju nedavno na polje e-glasanja, pa imamo radove na ovu temu, kao što su (Zhang, S., Wang, L., \& Xiong, H., 2020) i (Kshetri, N., \& Voas, J., 2018).
Ovaj rad se fokusira na polje koje nije dovoljno istraženo. Postavljene su dve hipoteze koje treba ispitati:

Hipoteza A: Omladina je prijemčiva za upotrebu elektronskog glasanja.

Hipoteza B: Studenti tehničkih i društvenih nauka imaju veoma slične stavove o upotrebi elektronskog glasanja.

Kao sinonim pojma omladine uzimamo mlade ljude, osobe koje su tek napunile godine potrebne za punoletstvo, a od svih tih mladih ljudi imali smo pristup studentima na jednom privatnom univerzitetu u dva grada Republike Srpske u Bosni i Hercegovini. Omladina sigurno ima najveći potencijal u upotrebi novih IKT, te je njen odnos prema e-glasanju prognoza buduće uloge e-glasanja.

\section{PRETHODNA ISTRAŽIVANJA}

U radu (Caporusso, L., Buzzi, C., Fele, G., Peri, P., \& Sartori, F., 2006) su ispitani stavovi $i$ iskustva glasača $u$ autonomnoj pokrajini Trento u Italiji. Telefonska ispitivanja su sprovedena pre i posle e-izbora 2005-te godine, kao i odmah po završetku e-izbora na licu mesta. Nama su interesantna ispitivanja pre tih e-izbora jer su slična našem ispitivanju - glasači nisu imali prethodna iskustva.

Rezultati govore da, bez obzira na pol, starost i obrazovanje, glasači imaju pretežno pozitivan stav o e-glasanju na izborima. Dalje se kaže na strani 196: "Mladi ljudi su mnogo bliži novim tehnologijama ali se manje interesuju za politiku; s druge strane, stariji građani manje veruju u elektronske metode glasanja, ali su veoma motivisani da učestvuju na izborima, jer za njih to nije samo pravo, već i dužnost." Mislimo da ovaj navod odgovara i našem području jer je u pitanju sličan mentalitet našem. 
U radu (Moynihan, D. P., \& Lavertu, S., 2012) se govori kako psihološke predrasude utiču na oblikovanje tehnoloških rešenja. Istraživanje je sprovedeno anketiranjem više hiljada lokalnih funkcionera $u$ administraciji SAD. U radu (Tsai, C. H., 2012) je sprovedeno istraživanje na Tajvanu koje kaže da što su ljudi zadovoljniji klasičnim načinom glasanja, slabije bi usvajali novi način, a to su uglavnom stariji ljudi, manje obrazovani i oni što podržavaju opoziciju. I na kraju, u radu (Powell, A., Williams, C. K., Bock, D. B., Doellman, T., \& Allen, J., 2012) se ispituje kakve namere mladi (uzrasta 18-25 godina) i stari (preko 60 godina) imaju u vezi izlaska na izbore sa udaljenom vrstom e-glasanja.

Koriste se tri osnovna pojma iz UTAUT (Unified Theory of Acceptance and Use of Technology) modela: očekivani napor korišćenja, očekivane performanse i društveni upliv sistema za eglasanje, da se definiše osam hipoteza. Zanimljiv je rezultat kako godine i pol utiču na nameru korišćenja e-glasanja. Godine delimično utiču na stav prema e-glasanju, a kod pola takav uticaj skoro da ne postoji.

\section{PODACI I ANKETA}

Pre nego što pređemo na samu anketu predstavićemo podatke iz informacionog sistema studentske službe univerziteta. Dobijeni su podaci o studentima sa svih fakulteta i smerova, sa osnovnih i master studija. Nažalost, nije dobijen podatak 0 aktivnim studentima $i$ pripadnosti studenata pojedinim fakultetima $i$ smerovima, jer se ovaj podatak smatra poslovnom tajnom. Podaci se nalaze na veb serveru u MS SQL Server relacionoj bazi podataka i dobijeni su direktnim izvršavanjem upita, jer su strukture podataka nestandardne $\mathrm{i}$ zato su napisani specijalno namenjeni SQL upiti.

Anketa je metoda ispitivanja indirektnog tipa gde se ispitanicima postavljaju pitanja u vezi teme ispitivanja a čiji odgovori ispitanicima su poznati ili je bitno njihovo mišljenje (Mihailović, D., 2004). Instrument ispitivanja je upitnik ili anketni listić, koga popunjavaju ispitanici, a koji ima ulogu posrednika između voditelja ispitivanja i ispitanika. Anketa je dobra za prikupljanje sociodemografskih podataka $i$ ispitanikovih stavova. Ova anketa je sprovedena kao ad hok i samostalno istraživanje, gde je njen cilj da se što više osvetle stavovi o e-glasanju. Ovom anketom se dodatno populariše e-glasanje kod anketiranih studenata ali i kod izvođača ankete (nastavnog kadra).

\subsection{Konstrukcija upitnika}

Upitnik mora da isprovocira i onda registruje tražene podatke, a od njegove konstrukcije zavisi uspešnost celokupnog postupka anketiranja (Mihailović, D., 2004). Upitnik je kratak i sažet, jer staje na jednu A4 stranu (slika 1). Sastoji se pripremno-završnog dela i glavnog dela sa pitanjima. Pripremno-završni deo je podjednako bitan kao i sama pitanja.

\footnotetext{
ANKETA MEĐU STUDENTIMA O ELEKTRONSKOM GLASANJU Fakultet: __ | Godina studija (I-IV): _ | Godina rođenja: 19 _ _ | Pol (M, Ž): _ Def.: Elektronsko glasanje (engl. e-voting) je novi način glasanja koji podrazumeva značajnu upotrebu elektronskih uređaja u izbornom procesu, što je najizraženije u samom činu glasanja. Postoji više tipova e-glasanja, a kao središnji tip se posmatra udaljeno eglasanje pomoću računara i/ili mobilnih telefona preko Interneta.

Molimo Vas da odvojite 5 minuta vremena i da iskreno i do kraja popunite ovu anonimnu anketu. Hvala.

1. Da li ste ranije čuli za e-glasanje? DA NE

2. Da li smatrate da je uopšteno gledano demokratija poželjan i dobar način vladavine? DA NE

3. Da li mislite da je demokratija u realnosti ispunila data obećanja? DA NE

4. Da li bi u našim uslovima verovali i koristili e-glasanje? DA NE

Da li bi u uslovima razvijenih zapadnih demokratija (npr. SAD, EU) verovali i koristili eglasanje? DA NE

6. Koliko uopšte možete imati poverenja u e-glasanje na opštim izborima? (1-nimalo, 2malo, 3-osrednje, 4-mnogo, 5-u potpunosti) 12345

7. Koja je verovatnoća da se tehnički perfektan sistem za e-glasanje može zloupotrebiti? (1-nikakva, 2-mala, 3-srednja, 4-velika, 5-sigurno) 12345

8. Da li ostali deo stanovništva van studentske i omladinske populacije bi mogao koristiti e-glasanje u našim uslovima? DA NE

9. Da li e-glasanje treba da bude:

1) jedini način za glasanje na izborima ILI

2) pretežni način za glasanje na izborima IL

3) opcioni način glasanja sa manjinskim učešćem.

10. Za koliko vremena će se početi koristiti po Vašem mišljenju e-glasanje za opšte izbore? 1) za __ godina ILI

2) nikad ILI

3) zavisi od

11. Da li vidite bar neku ključnu prednost kod e-glasanja (npr. nije potrebno ići na glasačko mesto, veća sigurnost, veće poverenje u izborni proces, odmah se znaju rezultati itd.)? DA NE

12. Napišite slobodno mišljenje ili primedbu u vezi e-glasanja.
}

\section{Slika 1: Izgled upitnika}

U zaglavlju je stavljen memorandum (zvanični logo) da bi upitnik dobio dozu ozbiljnosti pred studentima. Ispod je veliki naslov u kome piše da se radi o anketi među studentima o e-glasanju. Onda ide linija sa četiri socio-demografska podatka za popunjavanje: (1) fakultet (2) godina studija sa ponuđenim rasponom odgovora u zagradi (3) godina rođenja sa dva prazna mesta iza fiksnih „19“ cifara i (4) pol sa ponuđenim M i Ž opcijama u zagradi. $U$ normativno-edukativnom odeljku je data definicija e-glasanja $u$ dve rečenice, da bi utvrdilo tačno o čemu je reč u 
anketi. Definicija je jednostavna, bez mnogo stručnih termina, radi lakšeg razumevanja ispitanika. Uvodni tekst naglašava kratkoću popunjavanja upitnika (5 minuta), želju za popunjavanjem upitnika do kraja $i$ iskrenost jer je anketa anonimna. Onda ide kratka zahvala. U završnom tekstu pripremno-završnog dela se objašnjava svrha ankete i navodi ko je organizator i krajnji korisnik podataka dobijenih anketom.

U glavnom delu se nalazi 12 pitanja, naizmenično osenčenih radi lakšeg uočavanje međusobnih granica. Pitanja su kratka, tako njih 10 staje u jednom redu, a 2 su u dva reda. Zatvorenih pitanja ima 10, jedno je potpuno otvoreno i jedno je kombinovanog tipa. Od 10 zatvorenih 7 su sa binarnim izborom potvrde i odrečnosti (da/ne), jedno je sa tri isključujuća odgovora, a preostala dva su sa skalom Likertovog tipa od pet ponuđenih odgovora. Kombinovani tip pitanja ima tri isključiva odgovora gde se u prvom unosi broj, u drugom zaokružuje odgovor koji ima brojčani ekvivalent nule a treći odgovor je za neodređeni i uslovni sadržaj. Otvoreno pitanje je zadnje po redu, nije obavezno i ima tri reda prostora za uopšten odgovor po pitanju teme ankete.

Sadržaj pitanja je s početka uvodni (da li se čulo za e-glasanje), onda uopšte o demokratiji a nakon toga se kreće sa pitanjima o povezanosti demokratije i e-glasanja u lokalnim i svetskim uslovima. Slede pitanja o poverenju, mogućnosti zloupotrebe e-glasanja, kakvo je viđenje uloge eglasanja na izborima i kada će se početi koristiti e-glasanje.

\subsection{Sprovođenje ankete}

Posle štampanja većeg broja anketnih listića, pristupilo se izradi rasporeda mogućih termina anketiranja. Za termine su izabrani časovi predavanja i vežbi sa zvaničnog rasporeda na sajtu, tako da se pokriju sve godine svih fakulteta i smerova. Sa istog mesta se uočila osoba koja drži pojedine časove i onda se ista kontaktirala direktno ili preko posrednika. Po dogovoru se dolazilo na početak ili kraj časa, te bi se onda podelili anketni listići studentima. Naglašena je tema, kratkoća, lakoća, anonimnost i svrha teme anketiranja. Povremeno, ali ipak retko, je bilo dodatnih pitanja studenata.

Popunjeni anketni listići su se sakupljali i onda čuvali na zajedničkom mestu. Anketiranje je počelo sa početkom zimskog semestra akademske godine, u oktobru mesecu, a završilo se u prvoj polovini novembra, na obe lokacije univerziteta. Na prvom anketiranju je ocenjeno da je konstrukcija anketnog listića adekvatna i jasna ispitanicima, te se zato ovo prvo anketiranje posmatra kao uspešno pilot anketiranje i moglo se krenuti u sprovođenje do kraja.

Podaci dobijeni iz baze podataka univerziteta $\mathrm{i}$ podaci dobijeni anketiranjem studenata su anonimni. Iz njih nije moguće rekonstruisati prvobitni identitet studenata, iako je on bio nadohvat ruke (upiti su se izvršavali nad tabelom u bazi podataka gde su i ostali podaci o studentima, a u malim grupama anketiranih studenata se moglo lako zapamtiti ko je popunjavao koji anketni listić). Zanimljiva analogija se mogla napraviti između tajnog glasanja na izborima, gde konkretne osobe sa imenom i prezimenom (identitetom) biraju za koga će glasati i njihov izbor je anoniman, i naših ispitanika čiji podaci su dostupni u bazi podataka i dodatno oni sede pred očima organizatora anketiranja, ali su njihova mišljenja i izbori na anketnim listićima anonimni. $U$ oba slučaja postoji veza jednosmernog tipa, od osobe do izbora, a povratna veza je presečena i ne može se rekonstruisati.

\section{DESKRIPTIVNA STATISTIKA}

Ako se podaci dobijeni iz informacionog sistema univerziteta smatraju populacijom, onda je broj popunjenih anketnih listića veličina uzorka koji ćemo nadalje koristiti. Imamo ukupno 197 popunjavana anketna listića, a posle pregleda, ostaje 183 upotrebljivih listića, jer je toliko potpuno $\mathrm{i}$ ispravno popunjeno tj. imamo 183 slučajeva za dalju obradu $(7,11 \%$ invalidnih listića). Prvo će se opisati tabelama, slikama i frekvencijama slučajevi a onda će se preći na statističko zaključivanje o hipotezama. Broj slučajeva sa tekućom godinom studija je dat u tabeli 1. Za razliku od svih podataka iz studentske službe, kod anketiranih nije bilo niti jednog studenta drugog ciklusa studija odnosno studenata na master studijama. Po slobodnoj proceni službenika studentske službe (jer je takav podatak poslovna tajna) maksimalno ima $2-3 \%$ master studenata, a maksimalno $5 \%$ od ukupno upisanih studenata. 
Tabela 1. Studenti po tekućim godinama studija

\begin{tabular}{|r|c|}
\hline Prva godina & 93 \\
\hline Druga godina & 42 \\
\hline Treća godina & 38 \\
\hline Četvrta godina & 10 \\
\hline Prosečno & 46,75 \\
\hline Ukupno & 183 \\
\hline
\end{tabular}

Broj i razmjera muških i ženskih slučajeva su dati u tabeli 2.

Broj slučajeva koji studiraju pojedine fakultete je dat u Tabeli 3. Pošto anketirani univerzitet ima sedište u Republici Srpskoj, osnovan je i radi po njenim zakonima, i na kraju, pošto je većina upisanih studenata iz Srpske, primenićemo njen Pravilnik o naučnim i umjetničkim oblastima, poljima i užim oblastima iz 2009. godine, da razvrstamo fakultete u pripadajuće naučne oblasti. Razvrstavanje nam treba u kasnijim zaključivanjima.

Tabela 2. Broj i odnos muških i ženskih slučajeva u anketi

\begin{tabular}{|r|c|c|}
\hline & Apsolutno & Relativno \\
\hline Muški studenti & 105 & $57,37 \%$ \\
\hline Ženski studenti & 78 & $42,63 \%$ \\
\hline Ukupno & 183 & $100 \%$ \\
\hline
\end{tabular}

Tabela 3. Anketirani slučajevi po fakultetima i naučnim oblastima

\begin{tabular}{|c|c|c|c|c|c|}
\hline \multicolumn{6}{|c|}{ Naučne oblasti } \\
\hline Inženjerstvo i & \multicolumn{3}{|c|}{ Društvene nauke } & \multicolumn{2}{|c|}{ Humanističke nauke } \\
\hline $\begin{array}{c}\text { Fakultet za informacione } \\
\text { tehnologije }\end{array}$ & $\begin{array}{l}\text { Fakultet za ekonomiju } \\
\text { i menadžment }\end{array}$ & $\begin{array}{l}\text { Pravni } \\
\text { fakultet }\end{array}$ & $\begin{array}{l}\text { Poreska } \\
\text { akademija }\end{array}$ & $\begin{array}{l}\text { Filološki } \\
\text { fakultet }\end{array}$ & $\begin{array}{l}\text { Akademija } \\
\text { umetnosti }\end{array}$ \\
\hline 81 & 24 & 25 & 15 & 8 & 30 \\
\hline $100 \%$ & $37,50 \%$ & $39,06 \%$ & 23,44 & $21,05 \%$ & $78,95 \%$ \\
\hline $\mathrm{n} 1=81$ & \multicolumn{3}{|c|}{$n 2=64$} & \multicolumn{2}{|c|}{ n3 = 38} \\
\hline $100 \%$ & \multicolumn{3}{|c|}{$100 \%$} & \multicolumn{2}{|c|}{$100 \%$} \\
\hline $44,26 \%$ & \multicolumn{3}{|c|}{$34,97 \%$} & \multicolumn{2}{|c|}{$20,76 \%$} \\
\hline \multicolumn{6}{|c|}{$n=183$} \\
\hline \multicolumn{6}{|c|}{$100 \%$} \\
\hline
\end{tabular}

I konačno se daje sažeti pregled odgovora na prvih 11 pitanja (zatvorenog i kombinovanog tipa) za celi uzorak u Tabeli 4 . Većina podataka u tabelama i grafikonima koje su navedene u ovom odeljku su dobijene sa FREQUENCY() funkcijom u Excel softveru za tablične proračune.

Tabela 4. Pregled odgovora na prvih 11 pitanja ankete

\begin{tabular}{|r|r|r|r|r|}
\hline R.br. pitanja & \multicolumn{3}{c|}{ Odgovori sa apsolutnim i relativnim brojem (n je uvek 183) } \\
\hline Pitanje 1: & \multicolumn{2}{c|}{ Da: $124(67,76 \%)$} & \multicolumn{3}{c|}{$\mathrm{Ne:} 59(32,24 \%)$} \\
\cline { 2 - 5 } Pitanje 2: $67(36,61 \%)$ \\
\cline { 2 - 6 } Pitanje 3:
\end{tabular}




\section{STATISTIČKO ZAKLJUČIVANJE}

Za ovu svrhu je korišten IBM-ov statistički softver SPSS (Statistical Package for the Social Science) verzije 14, kao i reference (Vuković, N., 2003), (Mihailović, D., 2004). i (Pallant, J., 2009).

Pre nego što se pređe na statističko ispitivanje ostalih teze formiraće se agregatni indeks preko koga će se one dokazivati. Fokusiranje ide na praćenje indikatora koji su, po našem mišljenju, ključni za bolje prihvatanje elektronskog glasanja, što je mereno preko tzv. „indeksa otvorenosti ka e-glasanju“, u smislu pozitivnog izjašnjavanja ispitanika. Ovaj indeks je sastavljen od pet delova a koji se mere na osnovu odgovora na pet pitanja iz ankete. To su pitanja 4, 6, 7, 9 i 11. U tabeli 5. dat je pregled mera transformacije pitanja za uključivanje $u$ indeks otvorenosti ka e-glasanju.

Tabela 5. Pregled i transformacija pitanja i njihovih odgovora radi uključenja u indeks

\begin{tabular}{|cl|llll|}
\hline Pitanje: & $\begin{array}{c}\text { Originalna } \\
\text { skala: }\end{array}$ & $\begin{array}{c}\text { Raspon } \\
\text { skale: }\end{array}$ & $\begin{array}{c}\text { Skup } \\
\text { vrednosti: }\end{array}$ & $\begin{array}{c}\text { Potrebno } \\
\text { obrtanje: }\end{array}$ & $\begin{array}{c}\text { Pravila rekodovanja skupa } \\
\text { vrednosti: }\end{array}$ \\
\hline $\mathbf{4}$ & Binarna & $\mathrm{Da}-\mathrm{Ne}$ & $1(\mathrm{da}), 2(\mathrm{ne})$ & $\mathrm{Da}$ & $(1 \rightarrow 15)(2 \rightarrow 1)$ \\
\hline $\mathbf{6}$ & Likertova & $1-5$ & $1,2,3,4,5$ & $\mathrm{Ne}$ & $\begin{array}{l}(1 \rightarrow 15)(2 \rightarrow 11.5)(3 \rightarrow 8) \\
(4 \rightarrow 4.5)(5 \rightarrow 1)\end{array}$ \\
\hline $\mathbf{7}$ & Likertova & $\mathbf{1 - 5}$ & $\mathbf{1 , 2 , 3 , 4 , 5}$ & $\mathrm{Da}$ & $\begin{array}{l}(\mathbf{1 \rightarrow 1 5})(\mathbf{2} \rightarrow \mathbf{1 1 . 5})(\mathbf{3} \rightarrow \mathbf{8}) \\
(\mathbf{4} \rightarrow \mathbf{4 . 5})(\mathbf{5} \rightarrow \mathbf{1})\end{array}$ \\
\hline $\mathbf{9}$ & Tri stepena & $1-3$ & $1,2,3$ & $\mathrm{Da}$ & $(1 \rightarrow 15)(2 \rightarrow 7.5)(3 \rightarrow 1)$ \\
\hline $\mathbf{1 1}$ & Binarna & $\mathrm{Da}-\mathrm{Ne}$ & $1(\mathrm{da}), 2(\mathrm{ne})$ & $\mathrm{Da}$ & $(1 \rightarrow 15)(2 \rightarrow 1)$ \\
\hline
\end{tabular}

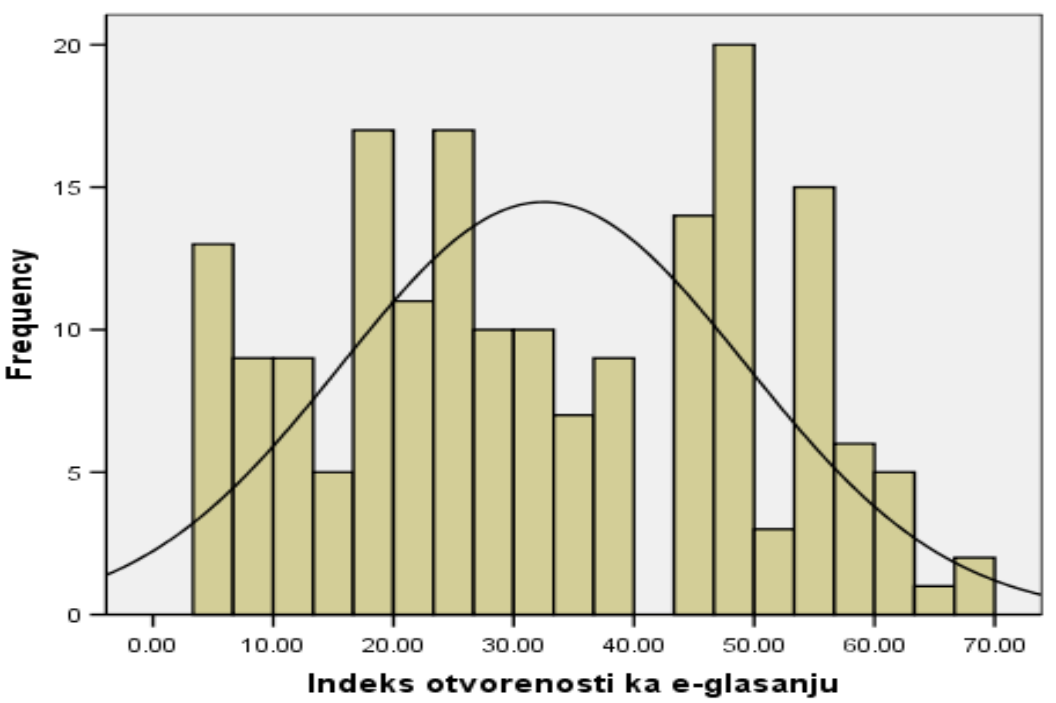

Mean $=32.4945$ Std. Dev. $=16.80651$
$\mathrm{~N}=183$

Indeks otvorenosti ka e-glasanju

Slika 2: Histogram indeksa otvorenosti ka e-glasanju

Prvi korak je obrtanje negativno formulisanih pitanja, ako ima takvih. Ishod obrtanja je takav da veće vrednosti u odgovorima ukazuju na veću otvorenost odnosno da iskazuju pozitivan stav ispitanika. Ako svi odgovori imaju istu važnost (težinu), onda treba skalirati dobijene vrednosti da budu $u$ istom rasponu (opsegu). Tako apsolutno odbijanje/prihvatanje treba da dobije najmanji/najveći mogući broj poena, dok vrednosti između (ako in ima) treba da budu ravnomerno raspoređeni tj. međusobno podjednako udaljeni. Nova skala kreće od 1 (najmanje pozitivan stav $\mathrm{tj}$. najmanje utiče na otvorenost ka e-glasanju) do 15 (najpozitivniji stav).

Hipoteza „Omladina je prijemčiva za upotrebu elektronskog glasanja" se ne može potvrditi, jer bi prijemčivost trebala proizvesti da frekvencije odgovora budu više na desnoj (pozitivnijoj) strani nego što je slučaj na grafikonu (slika 2.). Dodatno, srednja vrednost indeksa otvorenosti je 32,4945 gdje je polovina intervala vrednosti 45 nikako ne ide u prilog hipotezi. Slično je i sa medijanom od 32,5 .

Sledeća hipoteza „Studenti tehničkih i društvenih nauka imaju veoma slične stavove o upotrebi 
elektronskog glasanja" će biti ispitivana kao razlika između grupa studenata tehničkog i društvenog usmerenja. U Tabeli 3 . se vidi da prva grupa ima 81 ispitanika sa jednog fakulteta a druga grupa 64 sa tri fakulteta. Za ovu svrhu će se koristi t-test nezavisnih uzoraka, gde imamo dve promenljive u postupku testiranja:

- nezavisna promenljiva kategorijskog tipa sa samo dve vrednosti/grupe (studenti iz tehničke i društvene grupe) $i$
- zavisna promenljiva neprekidnog tipa (indeks otvorenosti ka e-glasanju).

Ako ne postoji značajna razlika između srednjih vrednosti ove dve grupe onda se studenti iz obe grupa ne razlikuju po otvorenosti ka e-glasanju tj. imaju isti stav po tom pitanju. Statističkim jezikom rečeno, ispituje se da li neke dve nezavisne grupe rezultata dolaze iz iste populacije.

\section{T-Test}

\section{Group Statistics}

\begin{tabular}{|l|l|l|l|r|r|}
\hline \multicolumn{2}{|c|}{ Kategorija } & N & Mean & \multicolumn{1}{c|}{ Std. Deviation } & \multicolumn{1}{c|}{ Std. Error Mean } \\
\hline Indeks otvorenosti & Tehničko polje & 81 & 34,3025 & 16,46259 & 1,82918 \\
ka e-glasanju & Društveno polje & 84 & 32,6719 & 17,71069 & 2,21384 \\
\hline
\end{tabular}

Independent Samples Test

\begin{tabular}{|c|c|c|c|c|c|c|c|c|c|c|}
\hline & & \multicolumn{2}{|c|}{$\begin{array}{l}\text { Levene's Test } \\
\text { for Equality of } \\
\text { Variances }\end{array}$} & \multicolumn{7}{|c|}{ t-test for Equality of Means } \\
\hline & & \multirow[t]{2}{*}{$\mathrm{F}$} & \multirow[t]{2}{*}{ Sig. } & \multirow[t]{2}{*}{$\mathrm{t}$} & \multirow[t]{2}{*}{ df } & \multirow[t]{2}{*}{$\begin{array}{c}\text { Sig. } \\
\text { (2-tailed) }\end{array}$} & \multirow[t]{2}{*}{$\begin{array}{l}\text { Mean } \\
\text { Differ. }\end{array}$} & \multirow[t]{2}{*}{$\begin{array}{l}\text { Std. Error } \\
\text { Differ. }\end{array}$} & \multicolumn{2}{|c|}{$\begin{array}{l}95 \% \text { Confidence } \\
\text { Interval of the } \\
\text { Difference }\end{array}$} \\
\hline & & & & & & & & & Lower & Upper \\
\hline \multirow{2}{*}{$\begin{array}{l}\text { Indeks } \\
\text { otvorenosti } \\
\text { ka } \\
\text { e- glasanju }\end{array}$} & $\begin{array}{l}\text { Equal variances } \\
\text { assumed }\end{array}$ & \multirow[t]{2}{*}{0,075} & \multirow[t]{2}{*}{0,784} & 0,573 & 143 & 0,568 & 1,6306 & 2,8471 & $-3,9973$ & 7,2585 \\
\hline & $\begin{array}{l}\text { Equal variances } \\
\text { not assumed }\end{array}$ & & & 0,568 & 130.5 & 0,571 & 1,6306 & 2,8718 & $-4,0506$ & 7,3118 \\
\hline
\end{tabular}

Slika 3. Rezultat $t$-test ispitivanja hipoteze $\mathrm{K}$

Sa slike 3. se vidi da nema statistički značajne razlike između grupa. Srednja vrednost (engl. mean) je za prvu grupu 34,30 a za drugu 32,67 (tabela Group Statistics), dok Leveneov test (tabela Independent Samples Test) potvrđuje jednakost varijansi obe grupe, Sig. 0,78. Konačno, pošto Sig. (2-tailed) iz iste tabele iznosi 0,57 i značajno je veći od granične vrednosti (praga) od 0,05, zaključujemo da nema razlika u otvorenosti ka e-glasanju studenata tehničke i društvene grupe.

Dodatno ako izračunamo eta kvadrat po formuli

$$
\text { Eta kvadrat }=t^{2} /\left(t^{2}+n 1+n 2-2\right)
$$

koji predstavlja veličinu uticaja između grupa, dobijemo vrednost 0,002 što je dosta manje od preporučene vrednosti 0,01 za mali uticaj (Pallant, J., 2009). Zaključujemo da je veličina razlike između grupa veoma mala, pored toga što je sam t-test rekao da je razlika neznačajna/slučajna između grupa.

\section{ZAKLJUČAK}

Predstavljenim podaci i analizom vidi se da nema razlike između studenata različitih fakulteta odnosno različitih područja studiranja kojima fakulteti pripadaju u pogledu otvorenosti prema upotrebi servisa elektronskog glasanja na političkim izborima. Ono što se nije moglo potvrditi je stav da studenti kao predstavnici omladine su prijemčiviji za upotrebu e-glasanja na izborima.

\section{DODATAK}

U tabeli 6. je dat pregled zanimljivih komentara na temu e-glasanju u sprovedenoj anketi. Oni su dobijeni kao odgovor na zadnje pitanje na anketnom listiću, koje je otvorenog tipa. Pretežan broj ispitanika nije popunio ovu rubriku, a ovdje su dati neki karakteristični koji bolje osvetljavaju stav ispitanika prema e-glasanju. Broj ispred komentara je redni broj slučaja, a komentari su ispisani različitom bojom osim onih za koje se ne može jednoznačno utvrditi kakav sadržaj imaju (uobičajena crna boja). 
Tabela 6. Semantički pregled komentara o e-glasanju

\begin{tabular}{|c|c|c|c|}
\hline Značenje boja: & (1) pozitivan stav & (2) negativan stav & (3) odmeren stav \\
\hline \multirow{2}{*}{\multicolumn{2}{|c|}{$\begin{array}{l}33 \text { - Velika je prednost što se ne mora ići na } \\
\text { glasačko mjesto, što bi posebno olakšalo } \\
\text { glasanje starijim osobama, ali je nedostatak } \\
\text { što oni vjerovatno ne bi u potpunosti znali da } \\
\text { ispune glasački „listićc. }\end{array}$}} & \multicolumn{2}{|c|}{$\begin{array}{l}22 \text { - Treba manje vremena, brže će se dobiti rezultati. } \\
\text { Primjedba je što u našim uslovima za sada nije pouzdano. }\end{array}$} \\
\hline & & \multicolumn{2}{|c|}{$\begin{array}{l}1 \text { - Mnogo efikasniji način glasanja, mnogo manje podložan } \\
\text { lažiranju rezultata. }\end{array}$} \\
\hline \multicolumn{2}{|c|}{$\begin{array}{l}18 \text { - E-glasanje je nešto što bi pozitivno } \\
\text { uticalo na uslove glasanja i uopšteno } \\
\text { pomoglo pravednom načinu izbora } \\
\text { odgovarajućih osoba (pod uslovom da se ovi } \\
\text { izbori odrade na ispravan način). }\end{array}$} & \multicolumn{2}{|c|}{$\begin{array}{l}51 \text { - E-glasanje je dobar način glasanja zbog uštede } \\
\text { vremena. U demokratiji će glasanje uvijek biti prevara bilo e } \\
\text {-glasanje ili ne. Starije stanovništvo se slabije snalazi na } \\
\text { računaru. }\end{array}$} \\
\hline \multirow{2}{*}{\multicolumn{2}{|c|}{$\begin{array}{l}26 \text { - Prevelika otvorenost ka manipulaciji. } \\
\text { Odlučivanje o budućnosti ljudskih života ne bi } \\
\text { nikada trebalo biti izloženo mogućoj } \\
\text { malverzaciji. }\end{array}$}} & \multicolumn{2}{|c|}{$\begin{array}{l}13 \text { - Mislim da je dobro zbog bržeg glasanja ali je lošije zato } \\
\text { što se može lako zloupotrebiti. }\end{array}$} \\
\hline & & \multicolumn{2}{|c|}{$\begin{array}{l}27 \text { - E-glasanje se na svaki način može zloupotrebiti i } \\
\text { namjestiti. }\end{array}$} \\
\hline \multirow{2}{*}{\multicolumn{2}{|c|}{$\begin{array}{l}84 \text { - lako smo demokratska država mi i dalje } \\
\text { nismo na nivou država kao što su SAD, EU, } \\
\text { Rusija. Postoji veliki broj ljudi koji bi } \\
\text { zloupotrebili ovakav način glasanja. }\end{array}$}} & \multicolumn{2}{|c|}{$\begin{array}{l}48 \text { - Što se tiče ovog glasanja kao i mnoge stvari ima i svoje } \\
\text { prednosti i nedostatke, mislim da je teško izvodljivo u našoj } \\
\text { državi. }\end{array}$} \\
\hline & & \multicolumn{2}{|l|}{12 - To neće biti nikad. } \\
\hline $\begin{array}{l}10 \text { - Mislim da bi } \\
\text { efikasnije ali se la } \\
\text { varanje. }\end{array}$ & $\begin{array}{l}\text { nostavnije, brže i } \\
\text { že zloupotrebiti za }\end{array}$ & \multicolumn{2}{|c|}{$\begin{array}{l}32 \text { - Korisno bi bilo da e-glasanje bude način glasanja jer bi } \\
\text { bilo brže i bilo bi teže za zloupotrebu. }\end{array}$} \\
\hline $\begin{array}{l}52 \text { - Ako ovaj vid } \\
\text { zemljama (Švajca } \\
\text { uvesti i kod nas b }\end{array}$ & $\begin{array}{l}\text { ja postoji u razvijenim } \\
\text { Švedskoj) može se } \\
\text { pštinsko glasanje. }\end{array}$ & \multicolumn{2}{|c|}{$\begin{array}{l}65 \text { - U našim uslovima (cjelokupnog regiona) i pored 100\% } \\
\text { perfektnog sistema našao bi se način za prevaru. }\end{array}$} \\
\hline $\begin{array}{l}100 \text { - Ako ništa dr } \\
\text { izračunali rezultat } \\
\text { je priča za sebe. }\end{array}$ & $\begin{array}{l}\text { ije bi se saznali i } \\
\text { upotreba i povjerenje }\end{array}$ & \multicolumn{2}{|c|}{$\begin{array}{l}101 \text { - Moje mišljenje da uz e-glasanje umanjujemo } \\
\text { mogućnost nasilja na šalterima te razvijanje nereda tokom } \\
\text { glasanja. }\end{array}$} \\
\hline \multirow{2}{*}{\multicolumn{2}{|c|}{$\begin{array}{l}130 \text { - Nepovjerenje u rad CIK-a jer smo } \\
\text { svjedoci slabog korišćenja IT-a. Nepovjerenje } \\
\text { u rad lokalnih izbornih komisija. }\end{array}$}} & \multicolumn{2}{|c|}{$\begin{array}{l}34 \text { - Moje mišljenje je da treba uvesti e-glasanje jer tako bi } \\
\text { bilo lakše narodu da glasa. }\end{array}$} \\
\hline & & \multicolumn{2}{|c|}{39 - Dobar predlog, ali težak za realizaciju. } \\
\hline $\begin{array}{l}43 \text { - Strogo sam p } \\
\text { veoma moguće i } \\
\text { zloupotrebe. }\end{array}$ & $\begin{array}{l}\text { glasanja samo radi } \\
\text { našoj državi }\end{array}$ & \multicolumn{2}{|c|}{69 - Treba se dobro realizovati i objasniti proces populaciji. } \\
\hline $\begin{array}{l}75 \text { - Smatram da } \\
\text { u potpunosti pređ }\end{array}$ & $\begin{array}{l}\text { jek nismo spremni da } \\
\text { a ovaj tip glasanja. }\end{array}$ & \multicolumn{2}{|c|}{$\begin{array}{l}88 \text { - S obzirom da danas većina populacije zna hakovati ovo } \\
\text { nije siguran način glasanja. }\end{array}$} \\
\hline $\begin{array}{l}116 \text { - Mislim da to } \\
\text { bolje da se držimc }\end{array}$ & $\begin{array}{l}\text { ravi način i da je ipak } \\
\text { g načina rada. }\end{array}$ & \multicolumn{2}{|c|}{$\begin{array}{l}119 \text { - Prednost = brži rezultati i efikasnije. } \\
\text { Mana = zloupotreba vodećih partija. }\end{array}$} \\
\hline $\begin{array}{l}129 \text { - To je glasar } \\
\text { mogućnost zloup } \\
\text { glasova. }\end{array}$ & $\begin{array}{l}\text { ućnosti, mala } \\
\text { glasača i njihovih }\end{array}$ & \multicolumn{2}{|c|}{$\begin{array}{l}125 \text { - Prednost je da nećemo morati izlaziti ali ima dosta ljudi } \\
\text { koji će glasati umjesto nekoga. }\end{array}$} \\
\hline 46 - Ne bi bilo pre & vanja glasova. & \multicolumn{2}{|l|}{56 - Hakovat će neko. } \\
\hline 59 - Nesigurno. & & \multicolumn{2}{|c|}{85 - Zloupotreba privatnosti. } \\
\hline 90 - Iskreno, ja ni & bih tako glasala. & \multicolumn{2}{|c|}{92 - Smatram daje e-glasanje beznačajno. } \\
\hline 106 - Mnogo više & bi glasalo nego inače. & \multicolumn{2}{|c|}{144 - Brže i jednostavnije. } \\
\hline 157 - Treba e-gla & & \multicolumn{2}{|c|}{183 - Demonokratija (sve su to đavolja posla). } \\
\hline
\end{tabular}




\section{CITIRANA DELA}

Caporusso, L., Buzzi, C., Fele, G., Peri, P., \& Sartori, F. (2006). Transition to electronic voting and citizen participation. In Electronic Voting 2006-2nd International Workshop, Co-organized by Council of Europe, ESF TED, IFIP WG 8.6 and E-Voting. CC. Gesellschaft für Informatik eV.

Cortier, V., Galindo, D., Küsters, R., Mueller, J., \& Truderung, T. (2016). Sok: Verifiability notions for e-voting protocols, In 2016 IEEE Symposium on Security and Privacy, pp. 779-798.

Krimmer, R., Volkamer, M., \& Dueñas-Cid, D. (2019). E-Voting - An Overview of the Development in the Past 15 Years and Current Discussions, doi: 10.1007/978-3-030-30625-0_1,

Kshetri, N., \& Voas, J. (2018). Blockchain-enabled e-voting. IEEE Software, 35(4), 95-99.

Kulyk O., \& Volkamer M. (2018). Usability is not Enough: Lessons Learned from Human Factors in Security Research for Verifiability. E-Vote-ID 2018, pp. 66-81.

Kusters, R., Truderung, T., \& Vogt, A. (2012). Clash attacks on the verifiability of e-voting systems. In 2012 IEEE Symposium on Security and Privacy, pp. 395-409.

Mihailović, D. (2004). Metodologija naučnih istraživanja. Fakultet organizacionih nauka Beograd

Moynihan, D. P., \& Lavertu, S. (2012). Cognitive biases in governing: Technology preferences in election administration. Public administration review, 72(1), 68-77.

Mursi, M. F., Assassa, G. M., Abdelhafez, A., \& Samra, K. M. A. (2013). On the development of electronic voting: a survey. International Journal of Computer Applications, 61(16).

Pallant, J. (2009). SPSS priručnik za preživljavanje. Beograd: Mikro knjiga.

Powell, A., Williams, C. K., Bock, D. B., Doellman, T., \& Allen, J. (2012). e-Voting intent: A comparison of young and elderly voters. Government Information Quarterly, 29(3), 361-372.

Tsai, C. H. (2012). Miracle Medicine for Curing Low Turnout? Evaluation of Electronic Voting in Taiwan, Annual Conference of World Association of Public Opinion Research, Hong Kong University

Wang, K. H., Mondal, S. K., Chan, K., \& Xie, X. (2017). A review of contemporary e-voting: Requirements, technology, systems and usability. Data Science and Pattern Recognition, 1(1), pp. 31-47.

Vuković, N., (2003). PC statistika i verovatnoća. Fakultet organizacionih nauka Beograd

Zhang, S., Wang, L., \& Xiong, H. (2020). Chaintegrity: blockchain-enabled large-scale e-voting system with robustness and universal verifiability. International Journal of Information Security, 9, 323-341. doi: 10.1007/s10207-019-00465-8

Received for publication:

24.12.2020.

Revision received:

09.02 .2021

Accepted for publication: $\quad$ 05.04.2021.

Kako citirati ovaj rad? / How to cite this article?

Style - APA Sixth Edition:

Pilipović, D., \& Gavrić, Ž. (2021, 04 15). Stavovi mladih prema elektronskom glasanju. (Z. Čekerevac, Ur.) FBIM Transactions, 9(1), 99-108. doi:10.12709/fbim.09.09.01.10

Style - Chicago Sixteenth Edition:

Pilipović, Dragoljub, i Željko Gavrić. 2021. „Stavovi mladih prema elektronskom glasanju.“ Urednik Zoran Čekerevac. FBIM Transactions (MESTE) 9 (1): 99-108. doi:10.12709/fbim.09.09.01.10. 
Style - GOST Name Sort:

Pilipović Dragoljub i Gavrić Željko Stavovi mladih prema elektronskom glasanju [Časopis] // FBIM Transactions / ur. Čekerevac Zoran. - Beograd : MESTE, 1504 2021. - 1 : T. 9. - str. 99-108.

Style - Harvard Anglia:

Pilipović, D. \& Gavrić, Ž., 2021. Stavovi mladih prema elektronskom glasanju. FBIM Transactions, 15 04, 9(1), pp. 99-108.

Style - ISO 690 Numerical Reference:

Stavovi mladih prema elektronskom glasanju. Pilipović, Dragoljub i Gavrić, Željko. [ur.] Zoran Čekerevac. 1, Beograd : MESTE, 1504 2021, FBIM Transactions, T. 9, str. 99-108. 